\title{
Thermal Conductivity Measurements with Different Methods; A Procedure for the Estimation of the Retardation Time
}

\author{
Ákos Lakatos, Ph.D*.; Imre Csáky; Ferenc Kalmár, Ph.D. \\ ”alakatos@eng.unideb.hu, imrecsaki@eng.unideb.hu, fkalmar@eng.unideb.hu \\ University of Debrecen, \\ Faculty of Engineering,
}

Department of Building Services and Building Engineering

H-4028, Debrecen, Ótemető utca 2-4. 302

*Corresponding author, first author

Phone: +36-52-415-155/77771

Fax:+36-52-415-155/77713

Abstract:

As it is known that nowadays, reduction of the heating energy loss of buildings is achieved mainly by thermal insulation. This is one of the most important objectives of buildings constructions and retrofitting of buildings. Therefore research, calculation and simulation on the energy efficiency of buildings are of great importance. In this paper we give an expansive presentation about the measurements of the thermal conductivity, heat flux and thermal resistance of individual insulation materials as well as in-built wall constructions executed in our laboratory. Thermal diffusion coefficients and wall delaying ability of the systems will be given resulting from the measurements. First of all, thermal conductivity measurement results of individual insulation materials achieved by a Holometrix type Heat flow Meter (HFM) will be presented. Afterwards, two different steady-state methods for measuring thermal resistance of wall structures (Calibration hot box method (CC) and Heat Flux measurements by Hukseflux (HF) apparatus) will be introduced. These measurements were accomplished through either an inbuilt plaster/brick/plaster wall construction insulated internally at the first time and later externally with different materials. The main target of this paper is the presented theoretical procedure for the estimation of the retardation time of wall structures. Furthermore in this publication the determination of thermal performance of Expanded Polystyrene Insulation (EPS) applied to walls in building constructions can also be found. Moreover numerical predictions for thermal resistance are presented. Besides, infrared thermographs were used to visualise the insulation ability of the layer structures. 
Keywords: Thermal conductivity, Holometrix, Hukseflux measurement, Calibrated hot box method

\section{Introduction}

In May 2010, a recast of the Energy Performance of Buildings Directive was adopted by the European Parliament and the Council of the European Union in order to strengthen the energy performance requirements and to clarify and streamline some of the provisions from the 2002 Directive it replaces. According to this new Directive, as of 31 December 2020 new buildings in the EU will have to consume 'approximately zero' energy and the energy will be 'to a very large extent' from renewable sources. Furthermore, for reducing the energy loss insulation materials are used. Accurate measurements of thermal conductivity of insulation materials, based on the out-dated existing standards, used in building technology are indispensible. Besides thermal conductivity the specific heat and the density will determine the thermal diffusion as well retardation time of the building structures. These parameters should be known in order to obtain proper information on the dynamic behaviour of materials during transient heat and moisture transfer processes. (Niachou et al. 2001, Xiao et al. 2009, ElSebaii et al. 2009, Tay et al. 2012, Goia et al. 2012, Dolado et al. 2011, Ozkahraman and Bolatturk 2006. Expanded Polystyrene (EPS) insulation material is a reasonable and the most frequently applied additional insulation in most countries of Europe, since its price and good thermal properties. lit can perfectly satisfy all of these criteria. These properties are published in previous papers. (Lakatos and Kalmár 2013a, Lakatos and Kalmár 2013b, Farhranieh et al. 2006, Yucel et al. 2009, Hourston et al. 1996, McCormick et al. 1959, Xiao et al. 2006, Morgan et al. 2002, Mihlayanlar et al. 2008, Nussbaumer et al. 2006, Changhai et al 2008). Several methods (e.g. Guarded Hot Plate Methods, Heat Flow meters, chamber methods) are available for the measurement of thermal conductivity what is the main thermal property of insulation materials. From the results of the measurements one can calculate the thermal resistance ( $R$-value) of materials and structures. Some of the thermal conductivities of individual thermal insulation materials can be found in literature or in standards and can be used with a good approximation however calculating the resistance of the multilayer structures with them could be imprecise. Furthermore the thermal conductivity values of materials can change (approximately by 10-20 or 42\%) through the in-building methods (see MSZ-04-140-21991 Hungarian standard). In Hungary this standard distinguishes the declared and design values of the thermal conductivities. This change depends from the insulation materials and from the mechanical fixings. As a result of this in-situ measurements of the thermal resistance of the in-built layer structures are significantly needed.

\section{Materials and methods}

\section{The heat technical laboratory}

The measurements were executed in our laboratory found in the University of Debrecen, Faculty of Engineering (in Hungary). Thermal conductivity of different 
materials can be measured in this laboratory. For measuring the thermal conductivity of the individual materials a Holometrix lambda 2000 Heat flow meter is used. The mechanism of the Holometrix equipment is clearly written in our latest papers (Lakatos and Kalmár 2013a, Lakatos and Kalmár 2013b). In order to measure the thermal resistance of in-built layer structures, an isolated chamber is available. The chamber is surrounded as well as divided into two rooms (cold and warm) with $2.2 \times 3.4 \mathrm{~m}$ areas each, by $0.5 \mathrm{~m}$ thick EPS 200 insulation system (see Figure 1.). The cold room can be cooled down to $250 \mathrm{~K}$ by three separated cryogenics. The warm room can be heated up to $298 \mathrm{~K}$ by a basic portable electric radiator. In the EPS dividing-wall $0.35 \mathrm{~m}$ over the ground a brick wall window, with $0.25 \mathrm{~m}$ thickness and $1.44 \mathrm{~m}^{2}$ surface area can be found. This brick wall is mortared with $0.015 \mathrm{~m}$ plaster (this is a conventional Ytong type mortar) both at the warm and the cold side (see figure $2 \mathrm{a}$ )). The brick wall was covered at first with a $0.002 \mathrm{~m}$ thick thermal insulation paint (TIP) at the warm side, afterwards with $0.05 \mathrm{~m}$ thick EPS 150 insulation materials at the cold side (see figure $2 \mathrm{~b}$ and $\mathrm{c}$ respectively). This paint contains a small quantity of ceramic hollow spheres. This is manufactured in a Hungarian plant.

\section{Experiments with Hukseflux apparatus}

Hukseflux (HF) HFP01 heat flux sensors serve the reason to measure the heat flux that flows through the object in which it is incorporated or on which it is mounted. Besides thermopile sensors measure the differential temperature across the ceramicsplastic composite body of HFP01. Working completely passive, HFP01 generates a small output voltage proportional to the local heat flux. The heat flux is calculated from the voltage. This instrument can measure the Heat Flux, and the R-value of building envelopes according to ISO 9869, ASTM C1046 and ASTM C1155 standards. These apparatus can be used from $250 \mathrm{~K}-350 \mathrm{~K}$ temperature range and it can measure from 2000 to $-2000 \mathrm{~W} / \mathrm{m}^{2}$ range with about $5 \%$ accuracy. The measurements were carried out by using two $\mathrm{HF}$ sensors with $0.5024 \times 10^{-2} \mathrm{~m}^{2}$ rounded surface for good spatial averaging fixed up at different points on the wall. For measuring the air temperatures at both warm and cold sides 2 pairs of thermo-couples belong to this apparatus. By using this apparatus one can reach an accurate value for the thermal resistance (R-value) measured by using the following equation,

$$
R^{H F}=\frac{\Delta T^{H F}}{\Phi^{H F}}
$$

where, $\Delta T^{\mathrm{HF}}=34 \mathrm{~K}$ is the average air temperature difference between the warm $\left(T_{1}=293\right.$ $\mathrm{K})$ and cold sides $\left(\mathrm{T}_{2}=259 \mathrm{~K}\right)$, and $\phi^{\mathrm{HF}}$ is the average of the measured heat flux. The best accuracy in the measurement values can be reached after the heat transfer through the wall structures reaches the steady-state stage.

For estimation of the R-value one can use the following equation: 
$R=\frac{1}{h_{i}}+\sum_{j} \frac{d_{j}}{\lambda_{j}}+\frac{1}{h_{e}}$

where, $h_{i}=8$ and $h_{e}=24 \mathrm{~W} / \mathrm{m}^{2} \mathrm{~K}$, both values were taken from the MSZ-04-140-2-1991 Hungarian standard, about the thermal sizing of buildings; similarly to Eq 2 . Are the heat transfer coefficients on the surface, $1 / h_{i}$ and $1 / h_{e}$ are giving the internal and the external surface resistances respectively, $d$ is the thickness of the wall (in $m$ ) and $\lambda(=k)$ is thermal conductivity.

\section{Measurements with the calibrated hot box method}

The determination of steady-state thermal resistance and thermal insulation of wall structures by calibrated hot box (CC) should be executed according to the MSZ EN ISO:8990 standard. The measurement set-up can be seen in Figure 3. The calibrated hot box is surrounded by air with fixed temperature parallel to its own, so as zero heat transfer can be expected through the wall of the box. Furthermore the box is made of $0.1 \mathrm{~m}$ thick EPS 200 enclosed between two sheets of wood with $0.02 \mathrm{~m}$ thickness. Temperature over the hot box was kept by basic portable, electric radiator.

Measurement of temperature both of the air and on the wall surfaces at both sides are measured by Pt-100 type thermocouples. The surface temperature of the walls was measured at 9 points arranged in equal distances from each other and the results were stored at data storage. The average value of surface temperature was calculated both at the warm and the cold sides from the measurement data. Inside the box a small fan was used for circulating air, and was heated by two bulbs with $40 \mathrm{~W}$ electric power either. Electric power of both the fan and the bulbs was measured outside the box with two calibrated electronic meters separately. At the cold side, one fan as well as two air baffles were used in order to reach a good air temperature homogenisation. From the measured surface temperatures of the wall the temperature difference can be calculated $\left(\Delta \mathrm{T}^{\mathrm{cc}}\right.$ in $\left.\mathrm{K}\right)$ in steady-state stage. From the measured electric power and the operating time ( $\mathrm{t}^{\mathrm{cc}}$ in $\mathrm{h}$ ) an average power ( $\mathrm{P}^{\mathrm{cc}}$ in $\mathrm{W}$ ) can be calculated. For achieving the thermal resistance of the layer structure, without the heat transfer coefficients, with $A^{c c}=1.44 \mathrm{~m}^{2}$ surface area, the following equation can be used:

$$
R^{C C}=\frac{\Delta T^{C C} \times A^{C C}}{P^{C C}}
$$

\section{Results and discussion}

\section{Thermal conductivity measurements with Holometrix lambda 2000}

Thermal conductivities of the EPS 200 and EPS 150 insulation slabs with geometry $(0.3 \times 0.3 \times 0.05 \mathrm{~m})$ each was tested with a Holometrix lambda HFM apparatus. Furthermore two pieces of EPS 150 slab were glued to each other with a $(0.001 \mathrm{~mm}$ thick) fixer and were examined also, this is an acryl-styrene based polystyrene fixing 
glue. It was important for investigating the role of the glue between two insulation materials, because the $0.05 \mathrm{~m}$ thick EPS samples were fixed on the brick wall only with this glue. Besides, these measurements were carried out in order to make sure about the laboratory values of the thermal conductivities of the EPS slabs. Four individual measurements were carried out on each sample. In table 1 , the average value evaluated from the thermal conductivity measurements with accuracies and the standards given from the manufacturer are represented in function of the measured densities. One can observe minimal difference between the thermal conductivity values given by the manufacturer and the measured ones regarding to EPS 150 however perfect match in " $\lambda$ " values can be found belonging to EPS 200. The thermal conductivity of the glued samples does not show deviances. Measurement results and discussion about the thermal conducitivities of different EPS materials can be found in (Lakatos and Kalmár 2013a).

\section{Thermal conductivity measurements with Hukseflux apparatus}

At first, as a calibration a test measurement with Hukseflux apparatus was carried on the $0.5 \mathrm{~m}$ thick dividing-wall. The measurement order can be seen in Figure 4 . The results of these measurements are presented in table 2. By using (Eq. 2) one can calculate the thermal resistance of the $0.5 \mathrm{~m}$ thick dividing-wall by using the thermal conductivity of the EPS 200 material given by the manufacturer. This value is about $\mathrm{R}=14.536 \mathrm{~m}^{2} \mathrm{~K} / \mathrm{W}$. By using $\mathrm{HF}$ apparatus a very low heat flux $\left(2.33 \mathrm{~W} / \mathrm{m}^{2}\right)$ was measured. From this very low heat flux and using (Eq. 1) $\Delta T^{\mathrm{HF}}=34 \mathrm{~K}, \mathrm{R}^{\mathrm{HF}}=14.587$ $\left(\mathrm{m}^{2} \mathrm{~K} / \mathrm{W}\right)$ can be calculated. The thermal conductivity estimated from this value is $\lambda=(\mathrm{k})=$ $0.034 \mathrm{~W} / \mathrm{m}^{*} \mathrm{~K}$. By achieving the same R-values these measurements became the base of further experiments. In Table 3 the calculated and measured values on the test-wall with different insulation layers can be found. At first, the calculated R-values, $R_{0}, R_{1}$ and $R_{2}$ belonging to the thermal resistance of the $0.015 \mathrm{~m} \_$plaster $/ 0.25 \mathrm{~m} \_$brick $/ 0.015 \mathrm{~m}$ plaster; the $0.015 \mathrm{~m} \_$plaster $/ 0.25 \mathrm{~m} \_$brick $/ 0.015 \mathrm{~m}$ plaster $/ 0.002 \mathrm{~m} \_$TIP and the $0.05 \mathrm{~m} \_E P S 150 / 0.015 \mathrm{~m} \_$plaster $/ 0.25 \mathrm{~m} \_$brick/0.015m plaster $/ 0.002 \mathrm{~m} \_$TIP are introduced respectively. For these calculations the " $\mathrm{h}$ ", and " $\lambda$ " values were taken from the relevant Hungarian (MSZ-04-140-2:1991) standard. After the steady-state measurements with $\mathrm{HF}$ equipment between $\mathrm{R}_{\mathrm{o}}$ and $\mathrm{R}_{\mathrm{o}}{ }^{\mathrm{HF}}$, furthermore between $\mathrm{R}_{1}$ and $\mathrm{R}_{1}{ }^{\mathrm{HF}}$ about $15 \%$ and $10 \%$ difference can be calculated. The thermal conductivity of both the thermal insulation paint from $R_{1}{ }^{H F}$, and the thermal conductivity value of EPS 150 from $R_{2}{ }^{H F}$ can be achieved by using the following equations:

$$
\begin{aligned}
& \lambda_{T I P}=\frac{d_{T I P}}{\left(R_{1}^{H F}-R_{O}^{H F}\right)}=\frac{0.002}{0.813-0.731}=0.024 \frac{\mathrm{W}}{\mathrm{m} \times \mathrm{K}} \\
& \lambda_{E P S}=\frac{d_{E P S}}{\left(R_{2}^{H F}-R_{1}^{H F}\right)}=\frac{0.05}{2.062-0.813}=0.04 \frac{\mathrm{W}}{\mathrm{m} \times \mathrm{K}}
\end{aligned}
$$

Figure 5, represents the position of the two HF sensors on the test area, moreover in Figure 6 the change in the heat flux regarding to the wall structures can be seen. A great 
heat flux fall can be noticed after using $0.05 \mathrm{~m}$ thick EPS 150 insulation on the wall structure. The minimal heat flux (about $2.5 \mathrm{~W} / \mathrm{m}^{2}$ ) was measured through the $0.5 \mathrm{~m}$ EPS 200 dividing wall.

\section{Thermal conductivity measurements with calibrated hot box}

The results of the measurements performed with calibrated chamber method are indicated in Table 4. From the difference of the wall temperatures $\left(\Delta \mathrm{T}^{\mathrm{cc}}\right)$, and from the average electric power $\left(\mathrm{P}^{\mathrm{cc}}\right)$ as well as the surface area by using (Eq. 3 ) the resistivities $\left(R^{c c}\right)$ of the wall structures can be calculated. The $R^{c c}$ values for each wall structure for the $0.015 \mathrm{~m} \_$plaster $/ 0.25 \mathrm{~m} \_$brick $/ 0.015 \mathrm{~m}$ plaster, and for the $0.015 \mathrm{~m} \_$plaster $/ 0.25 \mathrm{~m} \_$brick $/ 0.015 \mathrm{~m}$ plaster $/ 0.002 \mathrm{~m} \_$TIP as well as for the $0.05 \mathrm{~m} \_$EPS 150/0.015m_plaster/0.25m_brick/0.015m plaster/0.002m_TIP, are the following 0.434, 0.53 and $1.781 \mathrm{~m}^{2} \mathrm{~K} / \mathrm{W}$ respectively. From these values similarly to Eq. 4 and 5 thermal conductivities can be estimated:

$$
\begin{aligned}
& \lambda_{T I P}=\frac{d_{T I P}}{\left(R_{1}^{C C}-R_{O}^{C C}\right)}=\frac{0.002}{0.53-0.434}=0.021 \frac{\mathrm{W}}{\mathrm{m} \times \mathrm{K}} \\
& \lambda_{E P S}=\frac{d_{E P S}}{\left(R_{2}^{C C}-R_{1}^{C C}\right)}=\frac{0.05}{1.781-0.53}=0.04 \frac{\mathrm{W}}{\mathrm{m} \times \mathrm{K}}
\end{aligned}
$$

In Figure 7 the rise in the temperature difference of the walls is shown. One can see a remarkable change after the measurement implemented on wall coated with the $0.05 \mathrm{~m}$ thick EPS 150. Correlating to the results presented beforehand and shown in Figure 6 appreciably insulation can be reached by applying $0.05 \mathrm{~m}$ thick EPS. From the thermal conductivities of the EPS 150 insulation material measured by holometrix as well as HF and CC methods a correction factor used for in-built materials can be calculated by using (Eq. 8). This correction factor is mentioned in Hungarian standard (MSZ-04-140-2:1991) and it is approximately $\chi=0.42$. This value gives a percental $(\sim 42 \%)$ change of the thermal conductivities of EPS materials after fixing it on the building envelope. Before our measurements we fixed the EPS slabs only with acryl-type polystyrene bonding and did not use destructive mechanical fixings.

$$
\chi_{\text {measured }}=\frac{\lambda^{c c, H F}-\lambda^{\text {Holometrix }}}{\lambda^{\text {Holometrix }}}=\frac{0.04-0.036}{0.036}=0.1
$$




\section{Numerical calculations for the thermal diffusion and predicting the retardation of walls}

Numerical calculations were done for predicting the thermal diffusivity of the materials used for the experiments. The thermal diffusion coefficient $\left(D_{T}\right.$ in $\left.\mathrm{m}^{2} / \mathrm{s}\right)$ of a material can be calculated by using the following simple equation:

$$
D_{T}=\frac{\lambda}{\rho \times C_{p}}
$$

where, $\rho\left(\mathrm{kg} / \mathrm{m}^{3}\right)$ is the mass density and $\mathrm{C}_{\mathrm{p}}(\mathrm{J} / \mathrm{kgK})$ is the specific heat of the materials. (Lakatos and Kalmár 2013, Zamel et al. 2012) These predicted $D_{T}$ values are collected in table 5 and were calculated on the one hand from the measured one on the other hand from the values taken from the above mentioned Hungarian standard (MSZ-04-1402:1991). The values taken from the literature (declared values) are signed with a cross in table 5. If we plot these values we can see the lowest $D_{T}$ belongs to the thermal insulation paint and the highest is belonging to the EPS 150. This can be happened by the great difference between their mass densities, because their thermal conductivity and specific heat are nearly the same. These $D_{T}$ values are demonstrated in figure 8 . Brick and plaster are well-known and universally used building materials with acceptable thermal diffusion coefficients. For further calculations a theoretical by-pass should be taken. If we make a comparison of the first (Eq. 10) and second law of Fick (Eq. 11) with the thermal conductivity equations (Eq 12. and 13.) a simple similarity can be found:

$$
\bar{\jmath}=-D_{A} \times \operatorname{gradc}
$$

where $\underline{J}$ is the diffusion flux, $D_{A}$ is the atomic diffusion coefficient and gradc is the concentration (c) gradient. Representing the $2^{\text {nd }}$ law of Fick in one dimension and assuming that there are no sources and $D_{A}$ is constant, the following equation can be reached:

$$
\frac{\partial c}{\partial t}=D_{A} \times \frac{\partial^{2} c}{\partial x^{2}}
$$

where $\mathrm{t}$ is the time.

If we represent now the main equation of the thermal conduction and the Fourier's law, similar form of the equations to the above mentioned ones can be found:

$$
\bar{q}=-D_{T} \times \operatorname{grad} T
$$

where $\mathrm{g}$ is the heat flux, $D_{T}$ is the thermal diffusion coefficient and gradt is the temperature $(T)$ gradient. If we represent the Fourier's law in one dimension the following equation can be reached, by using the following assumptions: the sample is free from heat sources and $D_{T}$ is constant: 


$$
\frac{\partial T}{\partial t}=D_{T} \times \frac{\partial^{2} T}{\partial x^{2}}
$$

As Eq. 14 is the solution of the Fick's equation, for the first detection of the diffusing atoms (Lakatos et al. 2010 and Yi 2005), parallel to this Eq 15. can be a solution of the above mentioned thermal conduction equations. By rearranging Eq 15, a retardation time of the wall can be predicted from the $D_{T}$ values of the materials (Eq. 16).

$D_{A}=\frac{d^{2}}{4 \times t}$

where, $D_{a}$ is an atomic diffusion coefficient, $t(s)$ is an observing time, and $d(m)$ is the thicknesses (a sin eq. 2 presented) of the specimen (Hall and Morabito 1976, Lakatos et al. 2010).

$$
D_{T}=\frac{d^{2}}{4 \times t}
$$

$t_{\text {retardation }}=\frac{d^{2}}{3600 \times 4 \times D_{T}}$

Similar investigations and calculations had been presented by others in Ref. (He 2005, Gustafsson et al., 1986, Carslaw and Jaeger 2000, Waszink et al. 1990). This time unit value denoted in hours can give the retardation time of the given materials or layer structures against the thermal changes at the surface of the material. This retardation time can only be used for non-periodic, single thermal changes on the surface of the material with the above mentioned assumptions. The estimated retardation time for the declared and the measured values has been summarised in table 6 . For each wall structure the delays are represented. The initial plaster/brick/plaster system has 9.24 hours retardation time what can be increased by using the $0.002 \mathrm{~m}$ thick TIP and the $0.05 \mathrm{~m}$ thick EPS at the warm and the cold side up to nearly 9.4 hours. A hypothetic calculation can be seen in Figure 9 by using EPS 150 insulation with different thicknesses from 0 to $0.5 \mathrm{~m}$. One can detect a pure parabolic function between the thickness and the retardation time. After applying $0.4 \mathrm{~m}$ EPS insulation the time of the delay can be raised up to its double. Instead of the mathematical calculations represented by (Yi 2005 and Gustaffson 1986) and our intent was only to work out a novel and more simple method and for predicting the delaying ability of the wall structures.

\section{Visualisation by infrared thermographs}

Infrared thermographs were taken with TESTO 882 type thermo-camera on the cold side of the walls. All wall-structures were analysed with this apparatus after reaching the steady-state phase. A continuous fall in the temperature at the cold surface of the walls can be observed (see Figure 10). A small difference between Figure $10 \mathrm{a}$ and $\mathrm{b}$ can be detected, however the Figure $10 \mathrm{~b}$ and $\mathrm{c}$ thermographs show a numerous fall in the 
temperature. Figure $10 \mathrm{c}$ was taken after insulation with $0.05 \mathrm{~m}$ EPS 150 insulation materials at the cold side. If we choose an optional point, (eg.: right hand side) in the 3 pics, we could observe that between $\mathrm{a}$ and $\mathrm{b}$ about 2 , between $\mathrm{b}$ and $\mathrm{c}$ about 3-4 $\mathrm{K}$ temperature difference can be observed. An observable temperature rise can be detected in the warm side of the wall either. So that a great temperature difference can be noticed between the warm and the cold surfaces by application of an adequate insulation system.

\section{Conclusions}

In this comprehensive report a comparison of several measurement methods for evaluating the thermal conductivity, and thermal resistance of insulation materials and complete wall structures is presented. After the investigation of the materials we estimated a correction factor for the change in the thermal conductivity value of EPS 150 for building-in. From the thermal conductivity values measured with different methods thermal diffusion coefficients were calculated. A novel model theory was elaborated for a conservative valuation of the retardation times of the wall structures for non-periodic thermal effects. A hypothetic prediction for increasing the retardation time was given applying the above mentioned model by using EPS 150 insulations with different thickness. Our results point at for being a reliable insulation, EPS 150 with 0.2 $\mathrm{m}$ thickness should be used. With this thickness almost $12 \mathrm{~h}$ retardation can be reached. As well as that the main goal of this publication is the introduction of our new laboratory and the harmonization of our measurement methods. The thermal conductivity can be measured by three different ways, ex-situ and in-situ as well.

\section{Acknowledgements}

The work of the research group is supported by the TÁMOP-4.2.2.A-11/1/KONV-2012-0041 project. The project is co-financed by the European Union and the European Social Fund. „The research of Akos Lakatos was realized in the frames of TÁMOP 4.2.4. A/2-11-1-2012-0001 „National Excellence Program - Elaborating and operating an inland student and researcher personal support system convergence program". The project was subsidized by the European Union and co-financed by the European Social Fund."

\section{References}

Carslaw H.S., Jaeger J.C. (2000). Conduction of Heat in Solids (second ed.)Oxford Science Publications, New York

Changhai P., Zhishen W. Thermoelectricity analogy method for computing the periodic heat transfer in external building envelopes. Applied Energy 85 (2008) 735-754. 
Dolado P, Ana Lazaro A, Marin JM, Zalba B. Characterization of melting and solidification in a real scale PCM-air heat exchanger: Numerical model and experimental validation. Energy Conversion and Management, Volume 52, Issue 4, April 2011, Pages 1890-1907

El-Sebaii A.A., Al-Ghamdi A.A., Al-Hazmi F.S.,. Faidah Adel S. (2009 august. )Thermal performance of a single basin solar still with PCM as a storage medium. Applied Energy, Volume 86, Issues 7-8, Pages 1187-1195

Farhranieh, B., Sattari, S. Simulation of energy saving in Iranian buildings using integrative modelling for insulation. Renew. energy 2006, 31, 417-425.

Goia F, Perino M, Haase M. (November 2012), A numerical model to evaluate the thermal behaviour of PCM glazing system configurations. Energy and Buildings, Volume 54, Pages 141-153

Gustafsson S.E., Karawacki E.,. Chohan M.A. J. Phys. D: Appl. Phys., 19 (1986), pp. 727-735

Hall P.M., Morabito J.M.. Surf. Sci, 59 (1976), p. 624

Hourston, D.J., Song, M., Hammiche, A., Pollock, H.M., Reading, M., Modulated differential scanning calorimetry: 2 . Studies of physical ageing in polystyrene. Polymer, 1996; 37, 2:243-247

Lakatos A (2012). Investigation of water sorption properties of different insulating materials. Proceedings in Advanced Research in Scientific Areas The 1st Virtual International Conference. Zilina. Slovakia: EDIS, pp. 1827-1831. ISBN:978-80-554-0606-0

Lakatos A, Erdelyi G, Langer G.A, Daroczi L., Vad K., Csik A. D. L. Beke. (2010), Vacuum, 84 (7) pp. 953-957

Lakatos A, Kalmar F. (2013a) Analysis of Water Sorption and Thermal Conductivity of Expanded Polystyrene Insulation Materials. Building Services Engineering Research and Technology. Vol:34. Issue: 4. 407-416. 2013. DOI: 10.1177/0143624412462043

Lakatos A., F. Kalmar F. (2013b) Investigation of thickness and density dependence of thermal conductivity of Expanded Polystyrene insulation materials. Materials and structures Volume 46: Issue 7, 1101-1105. DOI: 10.1617/s11527-012-9956-5

McCormick, H. W. Brower, F.M., Kin, L. The effect of molecular weight distribution on the physical properties of polystyrene. Journal of Polymer Science, 1959;39, 135:87-100.

Mihlayanlar, E., Dilmac, S., Güner, A. Analysis of the effect of production process parameters and density of expanded polystyrene insulation boards on mechanical properties and thermal conductivity. Materials and design 2008; 29:344-352

Morgan, A. B., Richard H. Harris, Takashi Kashiwagi, Leonard J. Chyall, Jeffrey W. Gilman. Flammability of polystyrene layered silicate (clay) nanocomposites: Carbonaceous char formation. Fire and Materials 2002; 26, 6:247-253.

Niachou A, Papakonstantinou K, Santamouris M, Tsangrassoulis A, Mihalakakou G. (2001 september) Analysis of the green roof thermal properties and investigation of its energy performance Energy and Buildings. Volume 33, Issue 7, Pages 719-729

Nussbaumer T, K. Wakili, Tanner Ch. Experimental and numerical investigation of the thermal performance of a protected vacuuminsulation system applied to a concrete wall Applied Energy 83 (2006) 841-855 
Ozkahraman, H.T., Bolatturk, A. The use of tuff stone cladding in buildings for energy conservation. Constr. Build. Mater. 2006, 20, 435-44.

Tay N.H.S., Belusko M., Bruno F. (February 2012) Experimental investigation of tubes in a phase change thermal energy storage system Applied Energy, Volume 90, Issue 1, Pages 288-297

Waszink J.H.,. Hannen G.E.M. Hefsoni G. (Ed.), (1990), Proceedings of the Ninth International Heat Transfer Conference, vol. 3, Jerusalem, Hemisphere, New York pp. 193-198

Xiao W., Wang X., Zhang Y. Analytical optimization of interior PCM for energy storage in a lightweight passive solar room. Applied Energy, Volume 86, Issue 10, October 2009, Pages 2013 2018

Xiao, M., Sun, L., Liu, J., Li, Y., Gong, K. Synthesis and properties of polystyrene/graphite nanocomposites. Polymer 2006; 43, 8: 2245-2248

Yi He. Tehrmochimica Acta 436 (2005) 122-129

Yucel, K.T., Basyigit, C., Ozel, C. (2009) Thermal Insulation properties of expandedpolystyrene as construction and insulating materials Information on: http://zenonpanel.com.mk/al/wpcontent/uploads/2009/06/Thermal-Insulation-properties.PDF. Date of download. 2011-11-28

Zamel N, Becker J, Wiegmann A. (2012) Estimating the thermal conductivity and diffusion coefficient of the microporous layer of polymer electrolyte membrane fuel cells. Journal of Power Sources 207 70-80 
Tables and and captions:

Table 1: The thermal conductivity values of the EPS slabs measured by the Holometrix apparatus, compared to the declared values.

\begin{tabular}{|c|c|c|c|c|c|c|}
\hline & $\begin{array}{c}\text { Thermo } \\
\text { cell EPS } \\
150\end{array}$ & $\begin{array}{l}\text { Difference } \\
\text { from the } \\
\text { average } \\
\text { value }\end{array}$ & $\begin{array}{c}\text { Thermoc } \\
\text { ell EPS } \\
200\end{array}$ & $\begin{array}{l}\text { Difference } \\
\text { from the } \\
\text { average } \\
\text { value }\end{array}$ & $\begin{array}{c}2 \text { pieces } \\
\text { of } \\
\text { Thermoc } \\
\text { ell EPS } \\
\text { 150, } \\
\text { glued } \\
\text { together }\end{array}$ & $\begin{array}{c}\text { Difference } \\
\text { from the } \\
\text { average value }\end{array}$ \\
\hline$\rho\left(\mathrm{kg} / \mathrm{m}^{3}\right)=$ & 23.0363 & & 26.6233 & & 30,378 & \\
\hline $\begin{array}{c}\lambda_{1} \\
\left(W / m^{*} K\right)\end{array}$ & 0.03811 & 0.00125 & 0.034 & 0.00117 & 0.03686 & 0.0000285 \\
\hline $\begin{array}{c}\lambda_{2} \\
\left(W / m^{*} K\right)\end{array}$ & 0.03564 & 0.00122 & 0.0352 & 3.33E-05 & 0.03735 & 0.0005205 \\
\hline $\begin{array}{c}\lambda_{3} \\
\left(W / m^{*} K\right) \\
\end{array}$ & 0.03776 & 0.0009 & 0.035 & $0.00 E+00$ & 0.03673 & 0.0000995 \\
\hline $\begin{array}{c}\lambda_{4} \\
\left(W / m^{*} K\right)\end{array}$ & 0.03592 & 0.00094 & 0.0363 & 0.00113 & 0.03638 & 0.0004495 \\
\hline $\begin{array}{c}\lambda_{\text {average }} \\
\left(W / m^{*} K\right)\end{array}$ & 0.03686 & \pm 0.000539 & 0.0351 & \pm 0.00039 & 0.03683 & \pm 0.0001373 \\
\hline $\begin{array}{c}\lambda_{\text {declared }} \\
\left(W / m^{*} K\right)\end{array}$ & 0.036 & & 0.035 & & & \\
\hline
\end{tabular}

Table 2: The calculated and the measured thermal conductivity as well as thermal resistance values of the $0.5 \mathrm{~m}$ EPS 200 partition wall by using Hukseflux apparatus.

\begin{tabular}{|c|c|c|c|}
\hline $\begin{array}{l}\text { Calculated Resistance of } \\
\text { The EPS } 200 \text { Wall }\end{array}$ & $d(m)$ & & $R\left(m^{2} K / W\right)$ \\
\hline & & $\mathrm{h}=8$ & 0.125 \\
\hline \multirow[t]{3}{*}{ EPS 200} & 0.5 & \multicolumn{2}{|r|}{$\lambda_{\text {declared }}(\mathrm{W} / \mathrm{m} * \mathrm{~K})=0.035$} \\
\hline & & $h=8$ & 0.125 \\
\hline & & $\begin{array}{c}R \\
\left(\mathrm{~m}^{2} \mathrm{~K} / \mathrm{W}\right) \\
:\end{array}$ & 14.536 \\
\hline $\begin{array}{l}\text { Average measured heat } \\
\text { flux, } \lambda^{\mathrm{HF}}\left(\mathrm{W} / \mathrm{m}^{2}\right):\end{array}$ & 2.33354 & \multirow{3}{*}{$\begin{array}{c}\mathrm{R}^{\mathrm{HF}} \\
\left(\mathrm{m}^{2} \mathrm{~K} / \mathrm{W}\right) \\
: \\
\end{array}$} & 14.587 \\
\hline $\begin{array}{c}\text { Average measured air } \\
\text { temperature difference, } \\
\qquad \Delta \mathrm{T}^{\mathrm{HF}}(\mathrm{K}) \text { : }\end{array}$ & 34.0388 & & \\
\hline & & & $\begin{array}{l}\text { Measured thermal conductivity of } \\
50 \mathrm{~cm} \text { EPS } 200\left(W / \mathrm{m}^{*} \mathrm{~K}\right):\end{array}$ \\
\hline
\end{tabular}


Table 3: The calculated and measured thermal resistance as well as thermal conductivity values of the test-wall covered with different insulation layers by using Hukseflux apparatus.

\begin{tabular}{|c|c|c|c|}
\hline Calculated Resistance (1) & $d(m)$ & $\begin{array}{c}\lambda_{\text {Ideclared }} \\
\left(W / m^{*} K\right)\end{array}$ & $R\left(m^{2} K / W\right)$ \\
\hline & & $\alpha=8$ & 0.125 \\
\hline LB knauf premium plaster & 0.015 & 0.8 & 0.019 \\
\hline Solid brick & 0.25 & 0.72 & 0.347 \\
\hline \multirow[t]{3}{*}{ LB knauf premium plaster } & 0.015 & 0.8 & 0.019 \\
\hline & & $\alpha=8$ & 0.125 \\
\hline & & $\mathbf{R}_{\mathbf{o}}$ & 0.635 \\
\hline $\begin{array}{l}\text { Average measured heat flux, } \phi^{\mathrm{HF}} \\
\left(\mathrm{W} / \mathrm{m}^{2}\right)\end{array}$ & 46.8597 & & \\
\hline $\begin{array}{l}\text { Average measured air temperature } \\
\text { difference, } \Delta \mathrm{T}^{\mathrm{HF}}(\mathrm{K})\end{array}$ & 34.2467 & $\mathbf{R}^{\mathrm{HF}}$ 。 & $0.731 \pm 0.02$ \\
\hline \multirow[t]{2}{*}{ Calculated Resistance (2) } & $d(m)$ & $\begin{array}{c}\lambda_{\text {declared }} \\
\left(W / m^{*} K\right)\end{array}$ & $R\left(m^{2} K / W\right)$ \\
\hline & & $\mathbf{R}_{\mathbf{o}}$ & 0.635 \\
\hline \multirow[t]{2}{*}{ Thermal insulation paint: } & 0.002 & 0.02 & 0.1 \\
\hline & & $R_{1}\left(m^{2} K / W\right):$ & 0.735 \\
\hline $\begin{array}{l}\text { Average measured heat flux, } \phi^{\mathrm{HF}} \\
\left(\mathrm{W} / \mathrm{m}^{2}\right) \text { : }\end{array}$ & 42.0672 & & \\
\hline $\begin{array}{c}\text { Average measured air temperature } \\
\text { difference, } \Delta \mathrm{T}^{\mathrm{HF}}(\mathrm{K}) \text { : }\end{array}$ & 34.2064 & $\mathrm{R}^{\mathrm{HF}}{ }_{1}\left(\mathrm{~m}^{2} \mathrm{~K} / \mathrm{W}\right):$ & 0.813 \\
\hline $\begin{array}{l}\text { Measured thermal conductivity of } 2 \\
m m T I P, \lambda_{H F}\left(W / m^{*} K\right) \text { : }\end{array}$ & $0.024 \pm 0.003$ & & \\
\hline \multirow[t]{2}{*}{ Calculated Resistance (3) } & $d(m)$ & $\begin{array}{c}\lambda_{\text {declared }} \\
\left(\mathrm{W} / \mathrm{m}^{*} \mathrm{~K}\right)\end{array}$ & $R\left(m^{2} K / W\right)$ \\
\hline & & $R_{1}\left(m^{2} K / W\right):$ & 0.735 \\
\hline \multirow[t]{2}{*}{ EPS 150: } & 0.05 & 0.036 & 1.389 \\
\hline & & $R_{2}\left(m^{2} K / W\right)$ & 2.124 \\
\hline $\begin{array}{l}\text { Average measured heat flux, } \phi^{\mathrm{HF}} \\
\qquad\left(\mathrm{W} / \mathrm{m}^{2}\right) \text { : }\end{array}$ & 16.14 & & \\
\hline $\begin{array}{c}\text { Average measured air temperature } \\
\text { difference, } \Delta \mathrm{T}^{\mathrm{HF}}(\mathrm{K}) \text { : }\end{array}$ & 33.28 & $\mathrm{R}^{\mathrm{HF}}{ }_{2}\left(\mathrm{~m}^{2} \mathrm{~K} / \mathrm{W}\right):$ & 2.062 \\
\hline $\begin{array}{l}\text { Measured thermal conductivity of } 5 \mathrm{~cm} \\
\qquad E P S 150\left(W / m^{*} \mathrm{~K}\right) \text { : }\end{array}$ & $0.04 \pm 0.0017$ & & \\
\hline
\end{tabular}


Table 4: The measured thermal resistance as well as thermal conductivity values of the test-wall covered with different insulation layers by using calibration chamber method.

\begin{tabular}{|c|c|c|c|}
\hline $\begin{array}{l}\text { Calibration } \\
\text { chamber, } \\
\text { Wall } \\
\text { Resistivities }\end{array}$ & $\begin{array}{l}\text { Brick and } \\
\text { plaster }\end{array}$ & $\begin{array}{c}\text { Brick, plaster } \\
\text { and TIP }\end{array}$ & $\begin{array}{l}\text { Brick, plaster, } \\
2 \mathrm{~mm} \text { TIP and } \\
5 \mathrm{~cm} \text { EPS } 150\end{array}$ \\
\hline $\begin{array}{c}\text { Average } \\
\text { temperature } \\
\text { difference, } \\
\Delta \mathrm{T}^{c c}(\mathrm{~K}):\end{array}$ & 22.5 & 23.427 & 29.575 \\
\hline $\begin{array}{l}\text { Measured } \\
\text { Electric } \\
\text { Power, } \\
\text { (kWh): }\end{array}$ & 3.42 & 1.512 & 2.32 \\
\hline $\begin{array}{l}\text { Operating } \\
\text { time, } t^{c c}(h):\end{array}$ & 45.8 & 23.75 & 97 \\
\hline$P^{c c}(W):$ & 74.672 & 63.663 & 23.918 \\
\hline$R^{c c}\left(m^{2} K / W\right):$ & 0.434 & 0.53 & 1.781 \\
\hline \multirow[t]{3}{*}{$R^{\text {wall }}\left(m^{2} K / W\right)$ : } & 0.385 & 0.485 & 1.874 \\
\hline & & $\begin{array}{l}\text { Thermal } \\
\text { conductivity of } \\
2 \mathrm{~mm} \text { TIP. } \lambda^{\mathrm{cc}} \\
\text { (W/m*K): }\end{array}$ & $\begin{array}{c}\text { Thermal } \\
\text { conductivity } \\
\text { of } 5 \mathrm{~cm} \text { EPS } \\
150 . \lambda^{\mathrm{cc}} \\
\left(\mathrm{W} / \mathrm{m}^{*} \mathrm{~K}\right):\end{array}$ \\
\hline & & $\begin{array}{c}0.021 \pm 0.00081 \\
5\end{array}$ & $0.04 \pm 0.0011$ \\
\hline
\end{tabular}


Table 5: The calculated thermal diffusion coefficients $\left(D_{T}\right)$ of the individual materials. (The values with the cross, are the declared values and were taken from the literature MSZ-04-140-2-1991 Hungarian standard)

\begin{tabular}{|c|c|c|c|c|}
\hline & $\lambda\left[\mathrm{W} / \mathrm{m}^{*} \mathrm{~K}\right]$ & $\rho\left[\mathrm{kg} / \mathrm{m}^{3}\right]$ & $\mathrm{Cp}[\mathrm{J} / \mathrm{kgK}]$ & $\mathrm{D}_{\mathrm{T}}\left[\mathrm{m}^{2} / \mathrm{s}\right]$ \\
\hline Brick & $0.72^{+}$ & $1730^{+}$ & $880^{+}$ & $4.729375 \mathrm{E}-07$ \\
\hline Plaster & $0.8^{+}$ & $1700^{+}$ & $920^{+}$ & $5.115090 \mathrm{E}-07$ \\
\hline TIP. Calculated & 0.02 & 313 & $1080^{+}$ & $5.916460 \mathrm{E}-08$ \\
\hline $\begin{array}{c}\text { EPS 150 } \\
\text { calculated }\end{array}$ & 0.036 & 22.88 & $1460^{+}$ & $1.077689 \mathrm{E}-06$ \\
\hline $\begin{array}{c}\text { EPS 150 } \\
\text { measured }\end{array}$ & 0.04 & 22.88 & $1460^{+}$ & $1.197433 \mathrm{E}-06$ \\
\hline $\begin{array}{c}\text { EPS 200 } \\
\text { measured }\end{array}$ & 0.034 & 24.286 & $1460^{+}$ & $9.588928 \mathrm{E}-07$ \\
\hline $\begin{array}{c}\text { EPS 200 } \\
\text { calculated }\end{array}$ & 0.035 & 24.286 & $1460^{+}$ & $9.870956 \mathrm{E}-07$ \\
\hline
\end{tabular}


Table 6: The retardation times of the wall structures from the declared (taken from the MSZ-04140-2-1991 Hungarian standard) and measured thermal conductivities.

\begin{tabular}{|c|c|c|c|}
\hline $\begin{array}{c}\text { Wall } \\
\text { elements } \\
\text { with } \lambda_{\text {declared }} \\
\text { values }\end{array}$ & $\begin{array}{l}\text { Retardation } \\
\text { time (h) }\end{array}$ & $\begin{array}{c}\text { Wall } \\
\text { elements } \\
\text { with } \\
\lambda_{\text {measured }} \\
\text { values } \\
\end{array}$ & $\begin{array}{c}\text { Retardatio } \\
\text { n time (h) }\end{array}$ \\
\hline $\begin{array}{l}\text { Plaster } 0.015 \\
\text { m calculated }\end{array}$ & 0.0305 & $\begin{array}{c}\text { Plaster } \\
0.015 \mathrm{~m} \\
\text { calculated }\end{array}$ & 0.0305 \\
\hline $\begin{array}{l}\text { Brick } 0.25 \mathrm{~m} \\
\text { calculated }\end{array}$ & 9.1773 & $\begin{array}{c}\text { Brick } 0.25 \\
\text { m } \\
\text { calculated }\end{array}$ & 9.1773 \\
\hline $\begin{array}{l}\text { Plaster } 0.015 \\
\mathrm{~m} \text { calculated }\end{array}$ & 0.0305 & $\begin{array}{c}\text { Plaster } \\
0.015 \mathrm{~m} \\
\text { calculated }\end{array}$ & 0.0305 \\
\hline $\begin{array}{c}\text { Summarized } \\
1 \text { (h) }\end{array}$ & 9.24 & $\begin{array}{l}\text { Summarize } \\
\text { d } 1 \text { (h) }\end{array}$ & 9.24 \\
\hline $\begin{array}{l}\text { TIP } 0.002 \mathrm{~m} \\
\text { calculated }\end{array}$ & 0.0047 & $\begin{array}{l}\text { TIP } 0.002 \mathrm{~m} \\
\text { calculated }\end{array}$ & 0.0039 \\
\hline $\begin{array}{c}\text { Summarized } \\
2 \text { (h) }\end{array}$ & 9.2447 & $\begin{array}{l}\text { Summarize } \\
\text { d } 2 \text { (h) }\end{array}$ & 9.2439 \\
\hline $\begin{array}{l}\text { EPS } 150.0 .05 \\
m \text { calculated }\end{array}$ & 0.1611 & $\begin{array}{c}\text { EPS } 150 . \\
0.05 \mathrm{~m} \\
\text { calculated }\end{array}$ & 0.145 \\
\hline $\begin{array}{c}\text { Summarized } \\
3 \text { (h) }\end{array}$ & 9.4058 & $\begin{array}{c}\text { Summarize } \\
\text { d } 3 \text { (h) }\end{array}$ & 9.3889 \\
\hline
\end{tabular}




\section{Figure Captions:}

Figure 1: The sketch of the adiabatic measurement chamber.

Figure 2: The investigated wall-structures.

Figure 3: The measurement order of the calibrated chamber method.

Figure 4: The positions of the Heat flux sensors of the Hukseflux apparatus on the partition wall.

Figure 5: The positions of the Heat flux sensors of the Hukseflux apparatus on the test wall.

Figure 6: The measured heat fluxes in function of the measurement time.

Figure 7: The wall temperature differences in function of the measurement time.

Figure 8: The calculated thermal diffusivities of the different materials.

Figure 9: The predicted retardation times calculated from the measured and declared thermal conductivities in function of the thickness of the EPS.

Figure 10: The thermo graphical pictures of the walls on the cold side. A: the brick and plaster, B: Brick, plaster and TIP, C: Brick, plaster, TIP, and EPS 150. 